\title{
INCREASING COMMUNICATION AND CAPABILITY MATHEMATIC DISPOSITION OF SMA STUDENTS THROUGH EXPLORATION APPROACH
}

\author{
Wiwi Kartiwi ${ }^{1}$, Utari Sumarmo ${ }^{2}$, Asep Ikin Sugandi ${ }^{3}$ \\ ${ }^{1,2,3}$ IKIP Siliwangi, Cimahi \\ 1wiwikartiwi@yahoo.co.id, ${ }^{2}$ utari.sumarmo@yahoo.co.id, ${ }^{3}$ asepikinsugandi@gmail.com
}

Received: Jul 16 ${ }^{\text {th }}$, 2018; Accepted: Sep 29 ${ }^{\text {th }}, 2018$

\begin{abstract}
This research is a quasi-experimental study, which aims to examine the achievement and improvement of communication skills and the mathematical disposition of high school students through an exploration approach. The sample consisted of 2 classes with 68 students of XI level from one of the high schools in West Bandung. The instruments were each set of mathematical communication skills test descriptions, and a set of mathematical disposition scales. The study found that the achievement of mathematical communication skills of high school students who received learning with an exploratory approach was better than who received ordinary learning as a whole and their students' initial mathematical abilities. Likewise, the improvement of mathematical communication skills of students who received learning with an exploratory approach was better than those that received ordinary learning as a whole and the initial ability of their mathematical students. student. To achieve the mathematical disposition ability students whose learning uses an exploratory approach is better than students with ordinary learning as a whole and their initial mathematical abilities, there is no interaction between the exploration approach and the initial abilities that produce students' mathematical dispositions. There is also a sufficient relationship between students' communication skills and mathematical dispositions.
\end{abstract}

Keywords: Mathematical Communication Skill, Mathematical Disposition, Exploration Approach

\begin{abstract}
Abstrak
Penelitian ini merupakan penelitian kuasi eksperimen, yang bertujuan untuk menelaah pencapaian dan peningkatan kemampuan komunikasi dan berpikir kreatif serta disposisi matematik siswa SMA melalui pendekatan eksplorasi. Sampel terdiri dari 2 kelas berjumlah 68 siswa kelas XI salah satu SMA di Bandung Barat. Instrumen dalam penelitian ini adalah masing-masing satu set tes uraian kemampuan komunikasi matematik, dan satu set skala disposisi matematik. Penelitian menemukan bahwa pencapaian kemampuan komunikasi matematik siswa SMA yang mendapat pembelajaran dengan pendekatan eksplorasi lebih baik dari pada yang mendapat pembelajaran biasa ditinjau secara keseluruhan dan kemampuan awal matematik siswanya. Demikian juga peningkatan kemampuan komunikasi matematik siswa SMA yang mendapat pembelajaran dengan pendekatan eksplorasi lebih baik dari pada yang mendapat pembelajaran biasa ditinjau secara keseluruhan dan kemampuan awal matematik siswanya Namun ditemukan tidak terdapat interaksi antara pendekatan eksplorasi dan kemampuan awal matematik siswa yang menghasilkan kemampuan komunikasi serta disposisi matematik siswa. Untuk pencapaian kemampuan disposisi matematik siswa yang pembelajaranya menggunakan pendekatan eksplorasi lebih baik daripada siswa dengan pembelajaran biasa ditinjau secara keseluruhan dan kemampuan awal matematiknya, akan tetapi tidak ditemukan adanya interaksi pendekatan eksplorasi dan kemampuan awal yang menghasilkan disposisi matematik siswa. Disamping itu ditemukan pula adanya keterkaitan yang cukup antara kemampuan komunikasi dan disposisi matematik siswa.
\end{abstract}

Kata Kunci: Kemampuan Komunikasi Matematik, Disposisi Matematik, Pendekatan Eksplorasi 
How to Cite: Kartiwi, Wiwi., Sumarmo, Utari., \& Sugandi, A.I. (2018). Improving Communication Skills and Mathematical Disposition High School Students through Exploration Approach. . JIML 1 (3), 322-328.

\section{INTRODUCTION}

Mathematics according to (Andhiya, Sugandi, \& Novtiar, 2018) is applied science that is used in various disciplines of science and technology. The ability to think mathematics is the idea of mathematical activity that focuses on the ability that sees mathematics as an active process dynamic, generative, and explorative. The process in learning mathematics is called the term of high level mathematical thinking (high level mathematical thinking). One of the ability of high-level mathematical thinking is the ability of mathematical communication but in fact the average communication ability of students on average students are in low qualifications, especially in communicating mathematical ideas. This resulted in students rarely give a response because it has not been able to explain the ideas well. Students rarely ask because they have not been able to compile and make questions about mathematics as well as students less able to make conclusions from mathematics learned. The ability of mathematical communication has an important role because mathematics is an essential language that not only as a tool of thinking and solving problems but has unlimited value in conveying clear and precise ideas, and mathematics is the heart of science in social activities. Other important roles of mathematical communication skills are: to help students to sharpen the way students think, as a tool to assess students' understanding, to help students organize their mathematical knowledge, to help students build their mathematical knowledge, to improve their mathproblem-solving skills, advance their penalacies, build self-ability, social skills, and useful in establishing a mathematical community. The development of communication skills is a component of mathematical hard skill that is implemented in an integrated manner with the development of disposition as a soft skill component because of the relevance of applying concepts in problem solving, explaining and conveying ideas very closely related to the attitude of appreciating the usefulness of mathematics in life, curiosity, attention, and interest in learning mathematics, as well as a tenacious attitude and confidence in problem solving (Hendriana, Sumarmo, \& Rohaeti, 2013).

The abilities that must be possessed and developed by each individual student include the ability of communication and mathematical disposition in accordance with the purpose and vision of mathematical learning that contains the ability to communicate and appreciate the beauty and regularity of mathematical properties with the motivation and interest in learning to mathematics (Isnaeni \& Maya, 2014).

Communication in general can be interpreted as a way to convey a message with the intention to inform or convey opinions, or behavior either directly orally, or indirectly through the media. In order for the message conveyed can be understood by others then the technique needed to communicate with various languages including the mathematical language. In the process of learning mathematics in the classroom, communication of mathematical ideas can take place between teacher and student, between books with students, and or students with students. Mathematics learning conditions such as the opportunity to grow and develop skills and skills as well as terbinanya harmony of the classroom environment.

In addition to the abovementioned abilities, affective aspects of mathematical disposition of students is a major factor in determining student learning success. In accordance with the recommendations of the 2013 mathematics curriculum, the development of hard skills and mathematical soft skills or religious, social, knowledge and skills skills must be implemented 
simultaneously and in balance. The ability to reason, think systematically, critically and carefully, and a sense of beauty to the regularity of the nature of mathematics, the objective and open nature required in the face of an ever-changing future. Such cognitive traits and habits will cultivate mathematical disposition (Mathemathical Disposition), which is the desire, awareness and strong dedication to students to learn math and carry out various mathematical activities in everyday life.

In fact the problem that arises in the field that is related to the students is far from expectations. The tendency of students during this time is lazy to learn to dig and seek knowledge on the basis of his own desire. Despair finds difficulty in solving problems because of minimal knowledge. Based on the results of tests and surveys PISA (Program for International Students Assessment) in 2015 (released December 6, 2016) the performance of Indonesian students is still relatively low. Successively average achievement scores of Indonesian students for science, reading, and math are ranked 62, 61, and 63 of the 69 countries evaluated. The ratings and average Indonesian score does not differ greatly from previous PISA tests and surveys in 2012 which are also in the low material mastery group (Iswadi, 2016).

Therefore it is necessary a method of learning that can create a pleasant atmosphere in achieving the desired learning objectives. Among the learning methods that can be used to develop and improve communication skills and disposition of student mathematics is a method of learning with an exploratory approach. Students will learn well if they learn the way they like, and the learning process will be productive if the students are directly involved in learning. Exploratory learning is student-centered learning. In exploration activities students are required to perform various ways either formal or in the way of students themselves to find answers to an existing problem. The exploration approach provides students with the freedom to seek and explore information about the material learned by using various learning approaches, instructional media, and learning resources so that interaction between students with teaching materials, students with learning resources, students with students or students with teachers.

Stages of learning with exploration approach include: explorative problem, exploration, analyzing data or information obtained to solve explorative problem, presentation delivering individual or group exploration result. Conclude and reflect together (Khoerunisa, 2013) Based on the above description, the researcher felt compelled to carry out research in an effort to improve communication ability and mathematical disposition of high school students through exploration approach.

\section{METHOD}

This research method is quasi experiment. That takes two classes as a research sample. The first class gets the learning with the exploration approach and the second class gets regular learning. Before and after learning the two classes are given a parallel test that is about the ability to think creatively and the ability of mathematical communication. The research design according to (Ruseffendi, 2010) as follows :

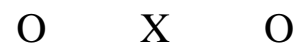

$\mathrm{O}$

With description : 
$\mathrm{O} \quad$ : Pretest is equal to postes of mathematical communication ability

$\mathrm{X} \quad$ : Learning with explorative approach

- - - - : Sampling is not random subject

Population in this research is all student of SMA Negeri in Regency of West Bandung. With the subject of the sample are two classes of students XI one of the SMA Negeri in West Bandung regency. Data obtained from the study were processed through the normality test, homogeneity test, and test the difference of two average, using SPSS software version 21.0 for Windows.

\section{RESULTS AND DISCUSSION}

\section{Results}

The results of research for mathematical communication ability are as follows:

Table 1. Descriptive Recapitulation of Communication Skills and Mathematical Disposition

\begin{tabular}{lllllllll}
\hline & & \multicolumn{3}{c}{ Experiment } & \multicolumn{3}{c}{ Control } \\
\cline { 3 - 8 } Variables & Instrument & Average & $\begin{array}{r}\text { \% of } \\
\text { ideal } \\
\text { score }\end{array}$ & SD & Average & $\begin{array}{r}\% \text { of } \\
\text { ideal } \\
\text { score }\end{array}$ & SD \\
\hline The Ability of & Pretest & 6,21 & 24,82 & 2,48 & 6,59 & 26,35 & 1,99 \\
\cline { 3 - 8 } $\begin{array}{l}\text { Mathematical } \\
\text { Communion }\end{array}$ & Postest & 19,35 & 77,41 & 2,92 & 16,09 & 64,35 & 3,03 \\
\cline { 2 - 8 } & N-Gain & 0,71 & & 0.14 & 0,52 & & 0.14 \\
\hline $\begin{array}{l}\text { Mathematical } \\
\text { Disposition }\end{array}$ & Postest & 71.85 & 78.48 & 5.58 & 64.12 & 69.69 & 8.26 \\
& & & & & & &
\end{tabular}

Ideal score of mathematical communication ability 25, ideal score of mathematical disposition 92

Data from the above table will be analyzed by normality test, homogeneity test, twodifference difference test, interaction test and association test as follows:

Table 2. Pretest Data Analysis

\begin{tabular}{lllll}
\hline Testing Data & Class & Normality & Homogeneity & $\begin{array}{l}\text { The difference is two } \\
\text { average }\end{array}$ \\
\hline $\begin{array}{l}\text { Pretest } \\
\text { Communications }\end{array}$ & Experiment & 0.132 & 0.219 & \multirow{2}{*}{0.486} \\
\cline { 2 - 5 } & Control & 0.233 & 0.219 & \\
\hline
\end{tabular}

Test results show that there is no difference in initial communication ability between classes using exploratory approach (experimental class) with ordinary learning (control class).

Table 3. Analysis of Postes and N-Gain Data for Achieving and Improving Student Mathematical Communication Skills

\begin{tabular}{lllll}
\hline Testing Data & Class & Normality & Homogeneity & $\begin{array}{l}\text { The difference is } \\
\text { two average }\end{array}$ \\
\hline postest & Experiment & 0.383 & 0.902 & 0.000 \\
\hline
\end{tabular}


326 Kartiwi, Sumarmo \& Sugandi, Improving Communication Skills and Mathematical Disposition High School Students through Exploration Approach.

\begin{tabular}{|c|c|c|c|c|}
\hline communication & Control & 0.457 & 0.902 & \\
\hline \multirow{2}{*}{$\begin{array}{l}\text { N-Gain } \\
\text { communication }\end{array}$} & Experiment & 0.386 & 0.940 & \multirow{2}{*}{000} \\
\hline & Control & 0.744 & 0.940 & \\
\hline
\end{tabular}

The results showed that the achievement and improvement of mathematical communication skills whose learning using exploratory approach is better than ordinary learning.

Table 4. Data Analysis of Student Mathematical Disposition Scale

\begin{tabular}{lllll}
\hline Testing Data & Class & Normality & Homogeneity & $\begin{array}{l}\text { The difference is two } \\
\text { average }\end{array}$ \\
\hline $\begin{array}{l}\text { Mathematical } \\
\begin{array}{l}\text { Disposition } \\
\text { Scale }\end{array}\end{array}$ & Eksperimen & 0.089 & 0.383 & 0.000 \\
\cline { 2 - 3 } & Control & 0.124 & & \\
\hline
\end{tabular}

From the results of research shows that the mathematics disposition of high school students who get the learning with exploratory approach is better than the ordinary learning reviewed in whole and the early ability of mathematics of the students.

Table 5. Interaction Analysis

\begin{tabular}{lllll}
\hline Testing Data & Class & Level KAM & Class*Level KAM & \multicolumn{2}{l}{ Interpretation } \\
\hline $\begin{array}{l}\text { N-Gain } \\
\text { communication }\end{array}$ & 0.000 & 0.001 & 0.432 & $\begin{array}{l}\text { There is no } \\
\text { interaction }\end{array}$ \\
\hline $\begin{array}{l}\text { Mathematical } \\
\text { Disposition }\end{array}$ & 0.000 & 0.000 & 0.285 & $\begin{array}{l}\text { There is no } \\
\text { interaction }\end{array}$ \\
\hline
\end{tabular}

The result of research shows that there is no interaction between the exploration approach and the students 'initial ability level in generating students' communication and disposition skills.

Table 6. Association Analysis

\begin{tabular}{lllll}
\hline Testing Data & Chi square & $\begin{array}{l}\text { Coefficients } \\
\text { Contingency }\end{array}$ & Interpretation & Category \\
\hline $\begin{array}{l}\text { Communication and } \\
\text { Mathematical Disposition }\end{array}$ & 0.042 & 0.357 & There is an association & medium \\
\hline
\end{tabular}

From the results of research shows that there is an association between communication ability and mathematical disposition of students both in the class that get exploration approach and in the class who accept regular learning with medium category.

\section{Discussion}

From the results of testing the data seen that at the beginning of learning either experimental class or control class have the same initial ability, seen from the test results that show no difference in average either seen from the method of learning or the level of early ability of mathematics students. Achievement of mathematical communication skills of high school students who get the learning with exploration approach is better than the class with ordinary learning. Achievement of communication skills can be seen from the difference of two average between students with exploration approach with ordinary learning. From the test results for mathematical disposition data, the results obtained that the student's mathematical disposition with learning with exploratory approach is better than ordinary learning. This is in 
line with the research conducted by (Nari, 2015)entitled "Communication Skill and Mathematical Disposition of Students in Geometry Course" stated that the mathematical disposition of students with the application of problem based learning strategy is better than students' mathematical disposition ability with the application of conventional learning method on a triangular, square rectangular and waxed building material using anchors and rulers. In addition, in a study by (Hendriana et al., 2013) entitled "Mathematical Communication Skills and Ability and Disposition of Critical Thinking Matemati (Experiment on High School Students Through Problem-Based Learning)" Several research results show that through a variety of innovative learning approaches students achieve better mathematical communication skills than students who acquire conventional learning.

Tests showed no interaction between exploratory learning and students' early math skills in generating mathematical communication skills. Based on the observations, there is a sufficient association or association between the communication skills and the mathematical disposition of the students either in the classroom which gets the exploration approach as well as in the class that gets regular learning. Overall we can say that the exploration approach is very helpful in improving communication skills and disposition of high school mathematics students.

\section{CONCLUSION}

Based on the results of testing and data processing above can be concluded that the achievement of mathematical communication skills of high school students who received learning with exploratory approach better than those who received regular learning reviewed overall and the initial ability of students. Similarly, improving the mathematical communication ability of high school students who received learning with better exploration approach than those who received regular learning reviewed in whole and the initial ability of the students. However, there was no interaction between the exploration approach and the students' early mathematical abilities that resulted in communication skills and mathematical disposition of students. For the achievement of mathematical disposition ability of students whose learning using exploratory approach is better than those with ordinary learning reviewed overall, but there is no interaction of exploration approach and initial ability that resulted in students' mathematical disposition. Besides, there is also a considerable relation between communication ability and mathematical disposition of students.

\section{REFERENCES}

Andhiya, Y., Sugandi, A. I., \& Novtiar, C. (2018). MeningkatkanKemampuan Komunikasi Matematis Siswa Kelas VIII MTs Negeri Sukasari Cimahi Pada Materi Sistem Persamaan Linear Dua Variabel Menggunakan Pendekatan Reciprocal Teaching. Jurnal Pembelajaran Matematika Inovatif, 1(2).

Hendriana, H., Sumarmo, U., \& Rohaeti, E. E. (2013). Kemampuan Komunikasi Matematik Serta Kemampuan Disposisi Berpikir Kritis Matematik. Jurnal Matematika Dan Pendidikan Matematika, 2(1).

Isnaeni, \& Maya, R. (2014). Meningkatkan Kemampuan Komunikasi dan Disposisi Matematik Siswa Sekolah Menengah Atas Melalui Pembelajaran Generatif. Junal Pengajaran MIPA, 19(2), 159-165.

Iswadi, H. (2016, December 7). Sekelumit Dari Hasil PISA 2015 Yang Baru Dirilis. Universitas Surabaya.

Khoerunisa, E. (2013). Peningkatan Kemampuan Pemecahan Masalah Dan Adversity Quotient Matematis Siswa MTs Melalui Pendekatan Pembelajaran Eksploratif. Univeritas Pendidikan Indonesia.

Nari, N. (2015). Kemampuan Komunikasi dan Disposisi Matematis Mahasiswa Pada Mata 
328 Kartiwi, Sumarmo \& Sugandi, Improving Communication Skills and Mathematical Disposition High School Students through Exploration Approach.

Kuliah Geometri. Ta'dib, 18(2).

Ruseffendi, H. E. T. (2010). Dasar-dasar Penelitian Pendidikan dan Bidang Non-Eksakta Lainnya. Bandung: Tarsito. 